\title{
Karlstadt's Wagen:
}

\section{The First Visual Propaganda for the Reformation}

Lyndal Roper and Jennifer Spinks

This remarkable cartoon, produced by artist Lucas Cranach and the Wittenberg theology professor Andreas Karlstadt, is almost certainly the very first piece of visual propaganda for the Reformation (German version, plate 1, and earlier, damaged Latin version, plate 2). ${ }^{1}$ Karlstadt was finalizing the Latin version of his broadsheet in January 1519; the first printed image of Luther, a crude woodcut adorning a tract printed in Leipzig, did not appear until at least six months later. The Reformation of course owed much of its success to its ability to exploit the new media of woodcut and print; and the partnership between the theologian Martin Luther and the Lucas Cranach, who lived just around the corner, was crucial to the Reformation's success. Cranach's famous portraits of Luther shaped his image throughout the entire sixteenth century. He collaborated with Philipp Melanchthon and Johann Schwertfeger, to produce the Passional of Christ and Antichrist in 1521, one of the most influential pieces of propaganda for the Reformation. Cranach's workshop produced the woodcuts for Luther's Bible, and as late as 1545, the two worked together to produce a series of scurrilous anti-Papal cartoons to accompany 
Against the Roman Papacy, the work Luther described as his testament. But as this cartoon demonstrates, it was Karlstadt, not Luther, who first conceived the idea of working with Cranach in the service of the new religious ideas, and who forged the partnership between artist and theologian.

As propaganda, however, Karlstadt's Wagen is a spectacular failure. For a movement which would go on to make the greatest use of the new medium of the printing press, and which would exploit the possibilities of the woodcut to the full, this broadsheet shows an astonishing inability to understand what can and cannot be conveyed in a picture.

Karlstadt's Wagen rolled off the press some time between January and March 1519, as the bitter controversy with Johannes Eck over the new evangelical ideas was becoming ever more impassioned. ${ }^{2}$ This culminated about six months later in the Leipzig debate, where Luther and Karlstadt faced Eck. Held during the summer months 'in good hiking weather', as one observer put it, in a specially furnished room in the castle at Leipzig, the Leipzig Debate attracted an audience of students and scholars from all over Germany. ${ }^{3}$ It was also a debate which Luther lost. His antagonist, the doughty Johannes Eck, built like a butcher and with a voice to match, tricked Luther into conceding that the Czech heretic Huss had been right to insist on communion in both kinds, and cornered Luther into taking more radical positions than he intended. 
The cartoon reveals a movement that was still finding its way. This image has none of the assurance of the Passional of Christ and Antichrist of 1521, produced just two years later. The contrast between the Wagen and the Passional reveals just how much the evangelicals had learnt from their first foray into visual imagery. The Passional is a visual classic that took its cue from old Hussite propaganda, and would continue to dominate the language of confessional imagery down to the end of the sixteenth century; Karlstadt's Wagen survives in only a few copies. ${ }^{4}$ In this paper, we want to explore the visual language of Karlstadt's Wagen. What were its sources, and what was its impact on the art of the Reformation? What does it reveal of nascent Reformation theology, long before Luther's theology could be neatly summarized in slogans, and long before his famous refusal to recant at Worms? And what can it tell us about how people were meant to view Lutheran propaganda?

\section{I}

The image itself is of remarkably high quality for a piece of propaganda. Its powerful visual design attempts to capture three dimensions, and uses shading to convey the horses' rounded bodies. Manes and bridles are cut with loving detail, while the stones on the road, one of Cranach's trade-marks, are drawn with their own shadows. About $30 \times 40 \mathrm{~cm}$ in size, bigger than A 3, it is divided horizontally into two, the upper section 
showing a cart being driven towards the cross and Jesus, the lower showing a cart travelling in the opposite direction towards the mouth of Hell. This binary structure of good versus evil would be exploited in a great deal of Reformation imagery, though nearly always the division is vertical, not horizontal - far easier for the eye to take in.

Yet the design as a whole is hard to make out, because the image is simply drowning in text. Partly this is because the mottoes of the earlier Latin version were briefer, and there was simply more German to fit into the space - a problem which led Karlstadt at first to despair of producing a vernacular edition at all. ${ }^{5}$ But even in the Latin cartoon, which survives only as a damaged fragment, words overwhelm the image. As we can see in the German whole, God the father is squeezed into the top of the image, his head cut off by the explanatory banderole above him, while Jesus cowers behind a gigantic cross of texts that almost conceals him altogether. Cranach’s landscapes are another casualty of the profusion of words. In the upper line we can just make out a wayside shrine and pilgrimage church with a traveller, whilst a round tower hints at a city further on; the dramatic craggy hills that appear so often in Cranach's paintings are reminiscent of the countryside beyond Dresden, the socalled Saxon Switzerland. But we can discern even less of the landscape in the bottom half, virtually obliterated by the huge scroll of writing. Where later images would contrast the 'good' 
landscape of the godly church with the ruined chapel of the papists, here the opportunity to make a visual point is squandered. Words are squeezed into every possible space. Mostly they are contained in their own scrolls, but in the German version, some lie loose in space, meander at an angle, or form their own rainbow. Abbreviated to the point of incomprehensibility, they are even run together so as to fit into their boxes, and sometimes Latin type is used instead of the correct German Gothic, as if the printer had run out of time.

The cartoon's comprehensive failure, however, has much to tell us about what made later Reformation visual propaganda so successful. Lutherans learnt to let images speak for themselves and when words were supplied, they were subordinated to images. This meant that even the illiterate could get the message. Lutherans learnt, too, to simplify. Karlstadt's Wagen does not use a settled visual language, with easily recognizable signs: only the devils, the hell mouth, and the cross instantly convey meanings, and even they are not clear. By the time Lutheran propaganda had developed in the early 1520s, Luther himself had become instantly recognizable, and Cranach and other artists brilliantly plundered demonology, scatology and popular culture to create a lexicon of images of the pope, monks, priests, and all that symbolised 'bad' religion. ${ }^{6}$ Indeed, this image works not as a piece of propaganda but as a visual aid to a series of meditative texts, that are intended to 
be read and re-read as part of a devotional process. In Latin, the words summarise key theological points in crisp sound bites, but so much is packed in that they are hard to understand. In German, the words are mostly rhyming doggerel, their scanning unmusical, their language painfully clumsy - 'Giss vor got dein hertz. Glaub im er hilft an Schertz’ (Pour your heart out before God, Believe him, he helps, it's no joke). ${ }^{7}$ The point, though, is not to entertain but to use rhyme as a memory aid. This poster is aimed at scholars and humanist educated pious layfolk, people, in short, from the circles in which Karlstadt himself moved. So while the broadsheet prefigures many techniques which later propaganda was to use so successfully - binary structures, processions, mockery, use of the diabolic- it is not a straightforward piece of propaganda. In 1519, Lutheranism was far from being a popular movement. There was not yet a recognizable Luther - Cranach’s famous etching was yet to come, and even the first image of the reformer, the crude Leipzig woodcut of Luther's face, had not been made. ${ }^{8}$ Still less was there a recognizable Lutheranism. And a culture of reading Lutheran images, of knowing how to look and interpret them, had yet to be developed.

\section{II}

Strikingly, Andreas Carolstadtius's name is right in the heart of the image, on the right at the top of the upper half; and his coat 
of arms on the upper right hand corner of the image asserts his authorship. ${ }^{9}$ Lucas Cranach’s own familiar logo of the winged serpent (already in regular use by 1519) is nowhere to be seen. Luther's name and image are missing too, even though his likeness would soon become such an important part of Lutheran propaganda, his face immediately recognizable.

Andreas Karlstadt was Luther's comrade in arms and closest ally. Yet the two men would gradually move in different theological directions until by 1522 Karlstadt was compelled to leave Wittenberg altogether. Once friends - and Luther acted as godparent to one of Karlstadt's children - they became enemies, even swearing a formal feud in $1524 .{ }^{10}$ Originally a convinced Thomist and scholastic, Karlstadt had become one of Luther's very first converts in the theology faculty at Wittenberg. Certain that Luther was misinterpreting Augustine, he set off for nearby Leipzig to buy his own copy, only to become persuaded that Luther was right about scholasticism. From then on he passionately took Luther's part. Luther meanwhile had not yet published the 95 Theses. He was just beginning to find his feet in the humanist world of letters, and was making connections through the group of humanists in Nuremberg centred around Christoph Scheurl. ${ }^{11}$

One of the humanists and anti-scholastics Scheurl wanted Luther to meet was Johannes Eck, and he arranged an introduction by letter, the two men exchanging exaggerated 
compliments and expressions of love. ${ }^{12}$ But shortly after Luther published the 95 Theses, his new friend Eck produced a brief set of theses which attacked them. Eck called them the 'Obeliscs', a printer's term which means things to be watched out for, errata. At first these circulated in manuscript. Luther was furious, regarding them as a betrayal of friendship. In reply he produced the 'Asterisks', another printer's term, for important points (even at this early date, both men paraded their fashionable awareness of the argot of the new medium of print). ${ }^{13}$ Karlstadt angrily took Luther's part, and before Eck had even published, he rushed a massive 380 Theses of refutation to the press, adding 26 more at proof stage. ${ }^{14}$ This was polemic by overkill, as if the sheer weight of counter-theses could destroy Eck's arguments. The publication forced Eck's hand. He broke publicly with Karlstadt and Luther, provoking Luther to publish as well, and he demanded a debate. For over a year, negotiations dragged on about where and how such a debate might be held, with Luther anxiously trying to rein in the impetuous Karlstadt, and Eck at first attempting to heal the breach.

Eck proved a far shrewder polemicist than Karlstadt. In response to his 406 theses, Eck designed twelve counter theses for the debate, which he had printed in Augsburg on December 29, 1518, on a single sheet. ${ }^{15}$ These were directed primarily against Luther. And then he added a thirteenth, number seven on free will, which at least appeared to be attacking Karlstadt's 
theology, the ostensible target. But it was Luther whom he had aimed to attack all along - Karlstadt had only ever been his stalking horse. Having helped negotiate the debate, Luther was snared, for he could hardly refuse to debate alongside Karlstadt, especially since his own positions were now clearly under attack. And so the Leipzig debate was born out of the debris of a broken friendship, Luther accusing Eck of acting out of envy and the desire for 'glory', Karlstadt insisting he was saving Luther's honour. ${ }^{16}$

The debate was held at Leipzig in summer 1519, in the territory not of Frederick the Wise but of his cousin Duke George. The Duke had not yet decided on his view of the Reformation, and the debate was instrumental in turning him into a formidable opponent of the Reformation, and of Luther: in Saxony at least, the debate marked the parting of the ways. By a fine irony, life would imitate art: Luther and Karlstadt travelled to Leipzig by wagon, accompanied by a large posse of Wittenberg students, some of them bearing arms. But Karlstadt's wagon, loaded with books, stuck fast just as they reached Leipzig, its wheels breaking. ${ }^{17}$ The broken cart turned out to be a true portent: Karlstadt, whose memory was poor, whose delivery was weak and who needed the comfort of books around him, was no match for Eck who had a prodigious memory and a talent for summary. Even Luther, a far better debater, did not fare well. 
For the nascent evangelical movement the Leipzig debate was a disaster. The outcome was to be adjudicated by the theology faculties of the universities of Erfurt and Paris, and they were understandably reluctant to show their hand in public in such a sensitive matter - Paris did not come up with a judgement until 1521, when it had long since ceased to be relevant. ${ }^{18}$ Until then, however, the text of the debate was not to be made public: and as a result, both sides soon resorted to publishing their versions of what had taken place. Luther soon realized his mistake in accepting conservative Paris and Erfurt as judges. He saw that Erfurt would not be on his side either, and tried to insist that all the professors, not just the theologians but the jurists, medics and members of the faculty of arts as well, should be consulted - to his opponents, a transparent strategy of damage limitation. ${ }^{19}$

The Leipzig Debate and its aftermath remained largely an internal quarrel amongst the learned, with all sides publishing in Latin and the points at issue becoming increasingly abstruse. It was Karlstadt who had been the first to reach out to a wider audience by printing a version of the Wagen in German in Spring 1519. And he knew how to make capital out of the image too: when the cartoon first appeared in March in Latin, over three months before the debate itself, he made sure to send a stack of copies to Spalatin, secretary to Frederick the Wise, who was to send them out to a series of important people. When he 
heard back from some of his 'supporters' that they could not understand the meaning of the top half of the Wagen, Karlstadt published his very first piece in German not Latin in April 1519, the Auszlegung, explaining what each figure meant. ${ }^{20}$

Yet there was one feature he was careful not to explain in print, the identity of the individual sitting on the cart bound for Hell, labeled 'self will'. As we will argue, this was almost certainly a portrait of none other than their antagonist Johannes Eck. ${ }^{21}$ Unexpectedly it was Eck, not Luther, who finally took the debate out of the academic ghetto. He published the entire correspondence between Luther, Karlstadt, the Elector and himself, translating it all into German. Just how far things had moved, however, was apparent in how Eck had to publish: the pamphlet was apparently assembled by his cousin Michael Eck, in the form of a set of letters sent to Johann von Schwarzenburg. The publication was designed to prove that Luther had been mendacious about the arrangements for the debate and to defend Eck against the slur that he taken on Luther out of 'envy' or had merely sought his own 'glory'. Published at Augsburg, the booklet headlined the work as 'Doctor Martin ludders Underricht an Kurfusten von Sachssen', and it might not have been apparent to the unwary purchaser that it stemmed in fact from Eck. ${ }^{22}$

The Wagen was undeniably a personal attack, and it probably fuelled Eck's vengefulness. Worse was to come: after 
the debate was over, a vicious anonymous satire against Eck, Eccius dedolatus, was published in Latin in February 1520, finally destroying Eck's reputation in humanist circles. ${ }^{23}$ In 1520 Eck travelled to Rome himself to secure the Bull against Luther, and amongst the names he added to the list of heretics were Karlstadt and Willibald Pirckheimer, the man whom he believed had written Eccius Dedolatus, and which evidently wounded him deeply. Karlstadt was profoundly shocked to find himself on Eck's list. Karlstadt's Wagen thus helped to ensure that not only Luther but Karlstadt too faced the possibility of being burnt as a heretic. The threat of martyrdom would colour Karlstadt's theology from then on. ${ }^{24}$

\section{III}

What does Karlstadt's Wagen depict, and what were the visual sources on which he drew? The interlocking iconographical details of the Wagen broadsheet have only ever been briefly and partially addressed. Unlike later, simpler works of Lutheran propaganda that would draw upon biblical motifs and clearly identified contemporary enemies, the Wagen is grounded in a welter of late medieval and Renaissance religious and humanist sources as well as contemporary points of reference. Karlstadt also seems to have been one of the first to use processional imagery for religious parody in the sixteenth century. All this conveys the ambition of the highly complex, large-scale work. 
Why did Karlstadt choose the format of the procession to Heaven and Hell? The broadsheet draws on the late medieval visual tradition of the mouth of Hell in manuscripts, on church portals, in block book Apocalypse cycles, and in prints depicting scenes such as the Last Judgment. ${ }^{25}$ The Hell mouth with its gaping jaws and accompanying demons was a familiar image. But the entry into Hell takes on new features here, with an extended procession of beautifully rendered horses travelling to in one direction toward Hell and in the other, to Heaven.

Karlstadt's use of the procession motif emerged from a larger cultural context, for processions were carriers of religious, cultural, social and political meaning in early modern Europe. Ephemeral processions such as Palm Sunday or carnival processions (some of which featured floats with representations of Hell) were a feature of church and civic life, though they would go on to be contested as the Reformation changed the face of religious ritual in many parts of Europe. Former knight Hans von Leonrod's (1439-1504) posthumous Hymelwag [und Hellwag] of 1517 (illustrated by Hans Schäuffelein) was Karlstadt's most direct visual source from a religious context, and reflects a very specific engagement with the late medieval spiritual world of the German lands. Two images from the book involve wagons: one depicts a good man going to Heaven in a wagon (plate 3), and the counterpart shows a wine-swilling man being carted off to Hell with his companion in the cart 
unconscious from alcohol (plate 4). ${ }^{26}$ But this was not the only source from which he borrowed. Processions recalled biblical passages - and ones that spoke directly to early Reformation concerns. Paul's words in the Letter to the Colossians 2.14-17 are particularly relevant (and Paul, as explained below, is one of the figures on horseback): 'He has wiped out the record of our debt to the Law, which stood against us; he has destroyed it by nailing it to the cross and he has stripped the sovereignties and the ruling forces, and paraded them in public, behind him in his triumphal procession' (Colossians 2.15). This passage goes on to question religious ritual, and was an important biblical passage for early reformers articulating rejections of scholastic philosophy. $^{27}$

Representations of processions both on foot and by wagon were fashionable, and Karlstadt and Cranach had their fingers on the pulse of the times when they used them as the basis for the image. ${ }^{28}$ Printed reconstructions of spectacular military triumphs from antiquity such as Venetian artist Benedetto Bordon’s 1504 Triumph of Caesar (after Jacob of Strasbourg) depicted the spoils of war paraded through Rome's streets in a work that reached northern European as well as Italian audiences (plate 5). ${ }^{29}$ Equally significant was the medieval tradition of the Petrarchan triumph, which in poetic form celebrated love, chastity, death, fame, time, and eternity. Florentine artist Francesco Pesellino’s cassone panel from c. 
1450 of Fame, Time and Eternity is a typical example of the associated visual tradition (plate 6), and demonstrates the likely broader European visual lineage of the elderly man in the Wagen. Newer types of imagery generated specifically Christian versions of the triumphal procession. Large Triumph of Christ prints appeared in Italy from c. 1510, in scenes often characterised by densely interactive visual and textual components. ${ }^{30}$ These visual motifs developed in Italian lands but the iconography circulated north of the Alps.

Karlstadt himself may very well have encountered similar works when he travelled to Rome and Siena to study law from late August 1515 to June $1516 .{ }^{31}$ He would write of his negative view of Rome as full of examples of papal pomp, processions included. ${ }^{32}$ Perhaps he therefore also had in mind the processions arranged in Italian cities from c. 1513 to 1515 to celebrate the accession of Pope Leo $\mathrm{X} .{ }^{33}$ One of the most magnificent, held in Florence on 30 November 1515, overlapped with Karlstadt's time in Italy, and would certainly have been a matter for discussion beyond Florence. ${ }^{34}$

The printed procession was also taking on increasingly contemporary relevance in German lands. In 1506 an illustration of the Triumphzug der Theologie by Wolf Traut appeared in Jakob Locher's collected works (plate 7). ${ }^{35}$ The figure of Theology is carried in a wagon and accompanied by various figures, including the Pope, and with a team of horses that have 
Moses as their driver. Karlstadt's Wagen is roughly

contemporaneous with the multi-sheet secular Triumphal

Procession of Maximilian planned from 1512 and completed predominantly by Hans Burgkmair the Elder - by 1519. This was part of Maximilian’s well-known wider deployment of printed propaganda, including the Triumphal Carriage of 8 blocks proposed by Albrecht Dürer and his humanist friend Willibald Pirckheimer in 1518, but not completed until 1522/23. ${ }^{36}$ Given the links between Wittenberg and Nuremberg, Karlstadt and Cranach would almost certainly have been aware of these ambitious new works of visual propaganda, executed or in planning, which gave the processional topos a contemporary twist and a politicised air.

Karlstadt is also very likely to have known of another, simpler single sheet print: the Triumphus Capnionis (plate 8). It depicts the Hebrew scholar Johannes Reuchlin in triumph, with various enemies chained and humiliated as part of the procession. Karlstadt was profoundly affected by the notorious controversy about Jewish books and declared his support for Reuchlin in letters to Georg Spalatin in 1514 and $1516 .{ }^{37} \mathrm{~A}$ version of the poem by Ulrich von Hutten that accompanies the woodcut and celebrates Reuchlin had circulated as early as 1514, but the woodcut first accompanied a printed version of the poem from $1518 .^{38}$ Like Karlstadt's Wagen, the Reuchlin scene is a parodic work that uses a 'religious' processional scene to 
attack enemies. Both invert the positive tradition of the Triumph and demonstrate a new stage in its use; one fundamentally connected to print culture and to religious controversy.

The Reuchlin broadsheet is a relatively simple work. Karlstadt's Wagen, on the other hand, is multidirectional, festooned with text, and aimed at many targets at once. It sought to articulate a complex theological position; to function at least partly as an Andachtsbild prompting pious reflection; to attack traditions of scholasticism; and to take aim at living enemies. It too was clearly parodic, and had Eck in its sights. Leipzig professor Andreas Frank von Kamenz informed Luther in a letter that students were being fined for laughing at the Wagen. ${ }^{39}$

\section{IV}

Is it possible to identify any of the individual figures in the broadsheet, or to assess their intended meaning? Karlstadt made conflicting statements about this. When planning the broadsheet he wrote to Georg Spalatin on 20 October 1518 that he would not identify people by name, but rather 'that anyone could tell they had been "bitten", if only they looked inside themselves'. ${ }^{40}$ After the fact, he cagily asserted that he had not named or depicted anybody, but simply pointed out theological errors. ${ }^{41}$

The upper zone of the image is entirely positive in tone. A haloed Augustine is the first rider, with Paul - also haloed following behind on the second horse. These two men are 
visually demarcated as the cornerstones of early Reformation thought. Augustine wears a bishop's mitre and elaborately decorated mantle. Just a few years later, this sort of clothing would be emblematic of all that was wrong with the Church of Rome, but here it is used to represent Augustine in positive terms. The aged man with the furrowed brow in the upper wagon represents 'a justified sinner, a penitent carrier of the cross' who accepts his punishment for sin and does not seek to escape it, as Karlstadt explains in the Auszlegung. ${ }^{42}$ He is emphatic that it is not a portrait, and that he has not depicted any friend or relative of his in this figure (plate 9). ${ }^{43}$

The wagon in which he sits is labeled 'Lex Dei currus ad Christum' (The Law of God/ Chariot to Christ), while a scroll on the side of the wagon contains a summary of the key ideas of Augustine's De Spiritu et Littera on the work of the law: it begins boldly with the word 'Lex' (the connection in the German is less clear and the reference to De Spiritu et Littera is missing). ${ }^{44}$ The old man is therefore a justified sinner, who has come to appreciate his own sinfulness through the Law, and is travelling towards the Cross. Augustine's treatise was, as we will see, very dear to Karlstadt's heart, and in 1519 he wrote a work on it himself.

The lower half of the scene plunges into a different world of diabolical, parodic, polemical print, literally depicting the highway to Hell. The only negative element in the upper section 
is an ineffectual demon underneath the upper cart, tugging fruitlessly at the wheels and shut out from the action. In the lower section, however, a devil greases an axel - as the text explains - so that the wagon will travel even faster on the path to Hell. The text includes several references to Aristotle, although it does not attempt to depict him visually; and it clearly presents an assault on scholasticism. Indeed, this would lie at the heart of Karlstadt's dispute with Eck in Leipzig.

One figure stands out in the bottom row: the man standing in the wagon bound for Hell (plate 10). A sturdy man gesturing emphatically, his distinctive features suggest that this is a portrait. In the Auszlegung, Karlstadt was suspiciously determined to rebut any suggestion that the figure in the upper wagon was a likeness of any individual, and immediately launched into a defence of his actions in commissioning the figure in the lower wagon, arguing that it did not represent a Dominican: no monk or Dominican, he argues, 'can prove that the above-mentioned figure is wearing a Dominican cassock. ${ }^{, 45}$ He was probably refuting the idea that the figure represented Cajetan, Luther's opponent in the discussions at Augsburg in 1518 and a convinced Dominican and follower of Aquinas. What he omitted to say, however, is just as revealing, for despite his outraged tone, he did not exactly deny that this lower figure was a portrait. Thirty-three at the time and a strong-bodied and physically dominant figure, Eck certainly thought that he was 
the man in the lower wagon, and reacted angrily, complaining that Karlstadt's Wagon had 'insulted me in a mocking way expressly by name'. Claiming to be above such foolishness he insisted 'I could just as well make a wagon, but I wouldn't put him [ie Karlstadt] in it' ${ }^{46}$ For his part, Karlstadt retorted that Eck had threatened to publish his own wagon but with asses, not horses: 'I'll let him make a wagon and put asses in it, if he likes', adding pointedly 'Perhaps an ass-driver will be found too! ${ }^{47}$ And in his response to Karlstadt, Eck wrote with heavyhanded irony: 'I didn’t complain about the image, because I thought he himself was sitting on the lower wagon. But since he goes at me with express words and insults me that if I put asses in the wagon, he would drive the asses, let it pass. If he can, he's fitted to be an Italian ass-driver', an insult that hinted at sodomy. ${ }^{48}$

Eck - if this figure indeed represents Karlstadt's bête noire - is accompanied in his wagon by a hairy beast whose clawed feet, female breasts, and single horn growing from its head all point to a diabolical nature. In Leonrod’s Hymelwag a knight is proffered alcohol by a bird-like devil with female breasts, clawed feet, and tufts of fur at the knees, elbows and shoulders (plate 11). ${ }^{49}$ In the c. 1520 anti-Lutheran Ketzerspiel broadsheet, a furry, breasted devil, with a single horn-like protrusion from its forehead would accompany Luther. ${ }^{50}$ This type of iconography evidently interested Lucas Cranach, for a 
few years later in c. 1525/30 he would paint a hairy, femalebreasted devil carrying a human to the Hell mouth, alongside a man and woman transported in a miniature wagon (plate 12 and plate 13). ${ }^{51}$ The hairy, devilish creature in Karlstadt's Wagen seems clearly intended to be read as diabolical.

The figure also seems intended to remind the viewer of the hairy Wild Man, a popular and sometimes positive topos in late medieval German culture, featuring in heraldic devices, decorative art, and carnival parades. ${ }^{52}$ The late medieval tradition was also often gendered and sexualised, with wild men tamed by women who aggressively (and thus unnaturally) assert their will. ${ }^{53}$ Satyrs - predominantly human in shape, but less than human in their nature - were also increasingly depicted around this time in similar ways. ${ }^{54}$ The theme of the hairy man as a debased human was widely understood, and amplified by Christian reference points including the case of Nebuchednezzar. ${ }^{55}$ The creature recalls Karlstadt's note in the Ausslegung that 'Saint Augustine said that the enemy lies within us' ${ }^{56}$ The diabolical wild man also acts as a polemical visualisation of Karlstadt's rejection of free will, as the figure in the Wagen holds aloft a sign saying 'I do what I please. The wagon carries me justly’ (ich du das ich mag. billich furt mich d'wag). The disconsolate, hairy devil of the Karlstadt broadsheet thus has no single iconographical lineage, but rather draws upon a range of references in order to demonstrate the low state of 
humanity, here quite literally reduced to the bestial and in thrall to the diabolical.

Other figures are still more difficult to read, and scholars have had little to say about the hunched man on horseback acting as the drayman or driver (plate 14). Yet he must play a significant role of some kind. Zschelletzschky argues that this figure is a 'doctor of scholasticism', and suggests a possible identification with the fifteenth-century Dominican Johannes Capreolus, who is briefly and negatively mentioned in the Auszlegung in connection with the concepts of free will and folly. ${ }^{57}$ Mühlhaupt simply observes that 'the rider on the next horse wears a monk’s vestments’ ${ }^{58}$ Karlstadt may perhaps have had a more specific Catholic target close to home in mind: Franciscans. In his Auszlegung, Karlstadt cites the text immediately below this figure and connects the passage to the barefoot orders (Barfuesser ordens). ${ }^{59}$ Karlstadt felt a special loathing for Franciscans and would go on to attack them (specifically those from nearby Annaberg) in print in $1520 .^{60}$ Leonrod's stress in the Hymelwag on the Fuhrman (drayman or driver) suggests that the function of this figure also deserves more attention. Although he sits in the traditional driver's position, close to the cart, he does not crack his whip energetically as Augustine and Paul do in the upper part of the broadsheet. In contrast, this unimposing and much more ambiguous figure merely extends his hand in a weak, ineffectual 
gesture.

The figure's role as a rider suggests an even more polemical possibility. Might Karlstadt have intended to suggest that he should be read as a pope? Pope Leo X - the great enemy of early reformers - was at this time forty-four. While he was more often depicted as heavy-set, Cranach may here offer a haggard and unflattering version of Daniel Hopfer's 1513-16 etched profile portrait of Leo X wearing a zucchetto, with bony, beaky nose, pouchy, hooded eyes, full lips, distinctively jutting chin and particular cheek-line (plate 15). ${ }^{61}$ By 1524, in the inflammatory broadsheet by Sebald Beham titled Die Höllenfahrt des Papstes, the Antichrist would be depicted as the pope in full regalia riding in the 'driver' position (plate 16). ${ }^{62}$

Yet reformers had not yet started directly attacking the individual Pope (as distinct from the papacy) in print at this point, and Karlstadt's own shift in this direction is thought not to have taken place before $1520{ }^{63}$ Nonetheless, the connection with horses and the role as a rider offer tantalising hints of what was to come. As noted above, Karlstadt decried the pomp of Rome after his Italian travels of 1515 and 1516, and may well have been gesturing towards the papal processions and the positive topos of the 'riding pope' that was particularly associated with the early papacy of Leo X. By October 1520 Karlstadt would firmly connect Leo X to horses in print when he included a section titled 'Of the many horses' ('Von den viel 
pferden') in his decisively antipapal pamphlet Von Bepstlicher heylickeit of 1520 which would specifically attack Leo X. ${ }^{64}$ Karlstadt argued that the pope should not own large numbers of horses or deck them out in expensive gear. ${ }^{65}$

But if an attack is being made already in this 1519 broadsheet, it is made purely in visual form, and the speech bubbles do not mention the papacy. Indeed, Karlstadt wrote to Georg Spalatin on 24 February 1519 that the broadsheet as a whole was intended to attack scholasticism, and anxiously declared 'in no way did I intend my wagon to scoff at the Pope in Rome'. ${ }^{66}$ Bubenheimer argues that Karlstadt's indecisiveness about the papacy at this time was grounded in a fear of losing his position as Archdeacon in the castle church at Wittenberg, and Karlstadt's own defensiveness may echo his anxious protestation that he had not attacked Eck. ${ }^{67}$ Any identification of this drayman figure must remain speculative, but it must have been intended to be read as an attack on some aspect of the Roman church in an addition to a broader attack on scholasticism, even if the attack is obscurely made and hesitantly executed.

The final figure at the very mouth of Hell is perhaps the most ambiguous of the entire broadsheet, and further demonstrates the failures of meaning that bedevil the Wagen as a piece of evangelical propaganda (plate 17). Is he friend or foe? As Mühlhaupt writes, he appears to be 'an unsuccessful Saint 
George' ${ }^{68}$ Why depict a saint, generally portrayed in both militaristic and highly positive terms, in this way? ${ }^{69}$ This figure seems to be the 'evil hero' (boser heldt) of the roughly cut banderole text unfurling from the pole he holds aloft. ${ }^{70}$ Other elements disrupt the standard iconography of St George in different ways: he is not dressed as a knight, but wears much simpler robes, has bare feet, and a knife and scabbard rather than sword. As such, he may also be inspired by Apocalyptic imagery, recalling that morally ambiguous agent of God, the Rider of the Pale Horse. ${ }^{71}$ But ultimately there is no satisfying visual parallel for this image, and we must turn to the accompanying text to attempt to make sense of it. The words, however, do not provide further clues for identifying an individual or group, but do indicate that this figure is depicted in order to redouble Karlstadt's attack on free will and good works: 'Drive on evil hero, We have chosen heaven for rich pay, by our own efforts done well' (Las faren boser heldt./wir haben den hymel erwelt./ Vmb reichen lon/ aus eigen krefften wolgethon). ${ }^{72}$ Yet the awkwardly cut-in text and the ultimately unreadable visual elements are symptomatic of the lower half of the broadsheet's failure to act as a piece of coherent visual propaganda intended to complement the Andachtsbild of the upper section. 
What kind of theology does Karlstadt's Wagen present? The main emphasis of the various texts is on the inability of human will to do good and the uselessness of human works for salvation. Humans must come to understand their own sinfulness through the Law. The upper half proclaims that Christ alone is the savior and the cross is paramount. 'God's mercy overcomes his justice' (Gottis barmhertzikeit vberlegt sein gerechtigkeit), 'Christ is our salvation' (Christus ist vnser selickeit), 'no-one can understand divine gifts without faith' (Keiner ist gotlicher gaben. an glauben. begreiflich). All the good works in the world are praiseworthy and punishable, says the banner under the hooves of the horse furthest to the left (Alle gute werck auf ertrich. Seynt loblich vnd streflich), a paradox which gets at the impossibility of any human works being untainted with sin. Only God’s grace can make things good. This is a fairly orthodox representation of Augustinian theology; while the Latin is more precise, the leaden rhymes of the German also make the message more crude. The targets of the bottom half of the image are Aristotle and faith in one's own works; the stocky Eck holds aloft banners reading 'our wills make the substance of good works' (Vnser wil macht guter werck substantz) and 'God's grace once given I can follow [geleben] without new help’ (gots gnaden eins gegeben kan ich an new hulf geleben). Karlstadt's point is that Eck claimed grace only had to be imputed to the Christian once - after that, the 
individual's own will could contribute to genuinely good works. Rather meanly, Eck is labeled 'own will' (Eigner wil), which is ambiguous between one's own will, and being self willed. But by the time we get to the right hand corner Karlstadt, tired of ventriloquizing his opponents, can no longer contain himself, and admonishes the reader that 'When I lived according to myself, I fell into the monster [ie Hell]; we should live according to God and give him alone the honour' (Do ich lebet noch mir. Vil ich in dz dir/ Noch got solten wir leben. Vnd ym allein ere geben).

There is nothing in the poster about scripture alone, and as we have seen, Luther makes no appearance. Instead the 'journey' the broadsheet asks the viewer to undertake is an emotional one, through recognition of our own absolute sinfulness, repentance, suffering and acceptance that we cannot do any good works. 'God works in us everything that he thinks good. He plants good will in us with fruits and roots' (Got in vns schaft. Alles dz er gut acht/ er pflantzt guten willen mit fruchten vnd wurzeln). This however is hardly conventional Lutheran theology, for it retains the idea that by conforming their will to God's will, the individual can become like Christ. To this extent, the cartoon's theology owes more to the Imitatio Christi tradition, familiar from the work of Johannes Staupitz, than it does to Luther. Vicar general of the Augustinians and Luther's confessor, Staupitz was the man Luther claimed was his greatest 
influence. He espoused a highly emotional spirituality, that built on the language of mysticism, even using intense eroticism to convey the 'sweetness' of Christ and advocating 'Gelassenheit', a state of letting go, in which the individual gives up their own self, desires and attachment so as to let Christ in. Initially Staupitz supported Luther, and the members of the sodality in Nuremberg around Christoph Scheurl were also admirers of Staupitz; for his part, in 1519 Karlstadt would dedicate his treatise on Augustine's De spiritu et littera, a work very close to his heart, to Staupitz. ${ }^{73}$

The Wagen was apparently successful. Karlstadt oversaw at least two versions of the cartoon, the first in Latin, the other in German. Generally well received, famous humanists like Scheurl and Pirckheimer in Nuremberg or Adelmann von Adelmansfelden sent copies delightedly to their friends. ${ }^{74}$ Yet Karlstadt appears never to have been comfortable with the image. Even Karlstadt's allies had trouble interpreting it, and told him so. Stung by the criticism, Karlstadt went in for overkill, penning a treatise - as we have seen - of over fifty pages in German to explain it, the Auszlegung.

In many respects, the Auszlegung shows a development in Karlstadt's theology, as he struggled to articulate exactly what he had meant in the cartoon. Some parts were too cryptic even for theologians who knew their way around all the abstruse debates: 'Regir dich nach deinem hochsten So kumst du tzu dem 
besten’ (Govern yourself according to your highest, so you will come to the best). Karlstadt glossed this as: some say that reason is the highest and most noble quality of man, but Augustine says that we should not live according to human reason but to God who is the greatest good. ${ }^{75}$ Even a Staupitzian could hardly have worked this out from the jingle in the broadsheet.

Sometimes, Karlstadt’s Auszlegung shows him simply trying to cram too much meaning into the image. He explains that the left side of the image behind the cross is meant to represent night and the rays of the cross, and provides an elaborate discussion of why this is so. But this simply cannot be conveyed in the tiny visual space of this section of the image. At other times, Cranach’s design fails to express what Karlstadt says he meant. For example, Karlstadt explains that two of the three scrolls underneath God the Father actually represent a discussion between God and the sinner: God says 'Tell me if you have anything with which you can come to me as justified' while man replies 'My flesh strives against my spirit, drawing me to the worst wickedness' (Sag mir ap du icht hast. Darumb du gerecht zu mir trabst. Mein fleisch streit gegem geist zu dem ergsten mich reist). ${ }^{76}$ Karlstadt seems to have meant these to be speech bubbles, but the middle scroll, which has nothing to do with the conversation, gets in the way. And Cranach's design doesn't help. At least God's words are loosely attached to God, but man's words are affixed to the end of Augustine's whip; and 
without Karlstadt's explanation, you could never work this out. So also, Karlstadt states that the frankly puzzling note that Christ holds in his left hand, and which is jammed side on into the very corner of the image, 'Glass will and you' (Glass willen vnd dich) actually reads 'Leave your own will, everything that is yours and you' (plate 18). ${ }^{77}$ This is one of Karlstadt's key ideas, but the viewer would have had to turn the image on its side to read it. It is meant to be balanced by the statement in Christ's other hand, also shown side on, 'Take your cross and follow me' (Dein creutz nim dir vnd volg mir). But the viewer can hardly make out the two hands, which are hidden behind the cross of texts, and they are in different typefaces, so they do not even look as if they are meant to be connected.

Interestingly too, Karlstadt's Auszlegung follows a strange route through the image. Karlstadt was never an orderly, logical thinker. Where Cranach’s image is meant be read from right to left in the top half, and then from left to right below, Karlstadt's Auszlegung starts with the Cross top left, with the need to love God, and with the concept of Gelassenheit. After a very full discussion of all the words and images surrounding the cross he turns to the barely visible God the Father, who is in the top middle of the upper half. Then he travels to the rider in the cart, Cranach's starting point. Where Cranach created an image that had a clear directional logic, Karlstadt seems to have wanted the 
image to be viewed not as a sequence, but as a series of discrete parts for meditation.

Karlstadt's reorganization has the result of putting the cross first, and allowing him to explain the concept that lies behind the whole image, Gelassenheit. In the cartoon, the word itself appears only as a negative. It sits in the bottom of the upper half, in the middle, in the incomprehensible rhyme 'Through wily lack of Gelassenheit, speakers of divine truth lie' (Durch listige vngelassenheit. Ligen redner gotlicher warhait). ${ }^{78}$ For Karlstadt, the whole image is to be read through the ideal of reaching Gelassenheit. This is what the reader has to grasp if they are to understand the image.

'Gelassenheit' was a key word of Staupitzian piety. It comes out of German mystical theology, and it would pass into the vocabulary of the later Anabaptists as well. It is a hard concept to convey. For Staupitz, it meant a kind of relaxed receptivity towards God and the divine will. When the Christian lets God in, so that God wills the individual's deeds, human will can be overcome and the Christian can become like Christ. This kind of theology is often allied with asceticism and suspicion of the flesh, and that is precisely what we find here: 'My flesh struggles against the spirit, pulling me to the worst things' (Mein fleisch streit gegem geist zu dem ergsten mich reist). Strikingly, Gelassenheit takes a central role in the broadsheet and in Karlstadt's explication of it, yet it is generally argued that 
it was not until 1520 that Gelassenheit became integral to his theology. Indeed, he would continue to ponder it all his life, devoting two treatises to it and planning a large work on it just before he died. Luther, on the other hand, would gradually retreat from Staupitz and the German mysticism he had once so admired. But while he never formally repudiated his mentor's theology, he later condemned Karlstadt outright for introducing what he considered to be a new kind of 'works theology': it simply was not possible, Luther argued, for the individual to become taken over by Christ's will in this way and so produce good works. Nor did Luther think in terms of the battle between flesh and spirit that was so important to Staupitz and Karlstadt. For Luther, the flesh was part of God's creation and so was no more evil than anything else.

Karlstadt's Wagen, then, prefigures much of Karlstadt's mature theology. It captures a moment in the development of Lutheran theology, before the differences between Luther and what would later become the Zwinglians and then the Calvinists were plain, and when an emotional, mystical piety could still be encompassed within Lutheranism.

Karlstadt did not repeat the experiment of working with artists and never again, so far as we know, undertook joint ventures with Cranach. For Cranach, it cannot have been easy to work with the proud, passionate theologian, who, to judge by the numbers of theses he devised against Eck, never knew when 
enough was enough. The fine workmanship of Cranach's image is in sharp contrast to the makeshift quality of the texts, their mixed typefaces, their mangled words and their awkward placing in relation to the image. Often they deface Cranach's brilliant draughtmanship. This can hardly have made for an easy working relationship.

If the Leipzig debate grew out of the emotional tangle of a friendship turned sour, similar forces may have been at work in the aftermath of Karlstadt's Wagen. The year after Karlstadt's Wagen appeared, Cranach began to work with Luther, creating the famous etching of the monk's face and designing the images which would be copied throughout Germany, and which would appear on the covers of Luther's famous Reformation tracts of 1520. When readers encountered Luther's mature theology, they often met it through Luther's person: his image literally prefaced the publication. Always fascinated by the possibilities of print, Cranach set up a press with his friend the goldsmith Christian Döring, and used it to publish Reformation propaganda, including the Passional of Christ and Antichrist on which he worked with Melanchthon. Meanwhile, the relationship between Luther and Karlstadt, once so passionate (on Karlstadt's side at least), cooled. Straight after the Diet of Worms in 1521, when Luther had been kidnapped and nobody knew he was bound for the Wartburg, it was to his friend Cranach that he wrote his very first letter, letting him know he 
was safe. ${ }^{79}$ By contrast, Luther never wrote to Karlstadt during the entire period of his stay at the castle. On his return in Spring 1522, he preached the Invocavit sermons which publicly condemned Karlstadt's theology and with it, all the steps that had been made under Karlstadt’s leadership to introduce a civic Reformation in Wittenberg. The breach between the two was complete. $^{80}$

\section{VI}

Along with Cranach, Karlstadt was the first reformer to grasp the propagandist possibilities of the printed image. But he also mistrusted pictures deeply, perhaps because he attributed them too much power. What seems to have disturbed him is the inherent instability of their meanings, their appeal to the senses, and their lack of directionality. While the Wagen had a clear division between the upper and lower section of the sheet, its individual elements led off in different and often confusing directions that were often further confused rather than clarified by the use of text. Disputations, on the other hand, followed a sequence. They had to be read in an order. Never a very coherent thinker himself, images - which could be read in many different directions and which teased the eye - may have worried Karlstadt because they represented the confusion of thought that was not organized into bite-sized pieces and that had to be grasped as a whole. 
Certainly, part of the function of the writing in the cartoon is to do exactly that, to turn the image into something that has to be read, meditated upon, and analysed, piece by piece. Indeed, the opening banderole invites the viewer to 'betrachten' or observe the 'wagon, together with the writings incorporated in it’ (wagen mit sampt eyngeleibten schrifften betrachten). ${ }^{81}$ But where Cranach created a directional, sequential image, Karlstadt insisted that the whole thing cannot be understood unless the viewer begins with Gelassenheit. Instead of progressing through the image, the pious Christian should focus on the message that different sections of the image convey. Each forms a whole, each conveys the same idea, but from different aspects. The kind of looking Karlstadt wanted from the viewer was devotional, not sensual. It owed a good deal to the late medieval vogue for pilgrimages of the inner eye, where pious Christians were encouraged to visualize the journey to the holy land step by step, training their minds to identify with Christ; or to the use of emblems on the covers of Staupitz's tracts, which set out the key ideas in crude visual terms. But where those were images in the service of ideas, Cranach's images were beautiful in and of themselves.

Just three years later, in January 1522, Karlstadt would become an iconoclast. When Luther was away in the Wartburg, groups of radicals took out and burnt altarpieces from the Franciscan monastery and tried to purge the Augustinian 
monastery as well. Karlstadt, following their lead, began to articulate a theology of opposition to images, and he went on to elaborate what he meant in a series of later tracts, especially once he left Wittenberg and created his own parish in Orlamünde. For the later Karlstadt, what was disturbing about images was their alluring emotionality. As he put it, 'Our eyes make love to [images] and court them. The truth is that all who honour images, seek their help, and worship them, are whores and adulterers.' They appealed to the flesh and not the spirit, and they took hold of the heart, where they seduced the viewer to love and worship them: 'my heart has been trained since my youth to give honour and respect to images and such a dreadful fear has been instilled in me of which I would gladly rid myself, but cannot. Thus I am afraid to burn a single idol. ${ }^{82}$ Karlstadt’s suspicion of images was thus profoundly linked to both his mysticism and his abiding asceticism. It sprang from a mistrust of the sensual. The first of the reformers to exploit the power of the image, he was also the first to articulate a theology of iconoclasm.

The broadsheet invites and resists explication with a rich but often unreadable range of reference points. It is ambitious but unsuccessful. Or was it? One way to address this question is to consider its influence on later, better-known examples of Lutheran printed propaganda. ${ }^{83}$ In particular, the oppositional structure of the Wagen may well have been influential. 
Cranach’s Passional of 1521 - which in a visually clear and satisfying series of vertically paired images contrasts Christ with the Pope, and incorporates riding scenes - is a key example. So too are the visually dynamic but fundamentally legible paintings and prints of Law and Gospel that Lucas Cranach would later produce. ${ }^{84}$

The Wagen likely also influenced the iconography of several important pieces of early Reformation imagery. The specific topos of the polemical procession would appear again in the 1524 Die Höllenfahrt des Papstes described above (see plate 16). The 1524 Triumphus veritatis poem by the likely pseudonymous 'Hans Heinrich Freyermut' incorporates a woodcut depicting Martin Luther, Ulrich von Hutten and Karlstadt walking ahead of Christ processing in a carriage (plate 19). ${ }^{85}$ The presence of Luther in this later Protestant broadsheet is a reminder of the absence of Luther in the 1519 Wagen, and the fact that Luther has no place in this earliest piece of evangelical propaganda in print.

Indeed, the fruit of the disagreement between Karlstadt and Luther can be seen today in the very different interiors of Calvinist and Lutheran churches. Lutheran churches are adorned with crucifixes and rich in visual imagery including pictures of Luther himself, while Calvinist churches are famously bare, ornamentation reserved for the pulpit and organ alone. Karlstadt's Wagen has much to tell us about one of the most 
fateful friendships of the Reformation, that between Luther and Karlstadt. When Karlstadt denied the Real Presence in the sacrament, the rift between the two men was complete, and as Luther saw it, Karlstadt was the progenitor of every radical heresy, from Müntzer to the Zwinglians, Anabaptists and spiritualists. By a fine irony, the man who commissioned the first piece of visual propaganda would become one of the first to turn against the religious use of images altogether. Cranach would go on to develop the technique of contrast and antithesis, creating one of the most powerful forms of propaganda ever seen. But the use of contrast was not confined just to images that mocked and condemned: he would also explore its devotional possibilities, allowing viewers to grasp and ponder Luther's deepest theological arguments. In this respect, Karlstadt's Wagen was also the precursor of a distinctively Lutheran form of art.

\section{Notes}

\#

${ }^{1}$ The most important studies of the broadsheet are: Erwin Mühlhaupt, 'Karlstadts “Fuhrwagen”. Eine frühreformatorische “Bildzeitung” von 1519’, Luther 50, 1979, 60-76; Hans-Georg Thümmel, 'Karlstadts und Cranachs “Wagen”, in Jörg Haustein and Harry Oelke, eds, Reformation und Katholizismus. Beiträge zu Geschichte, Leben und Verhältnis der Konfession. Festschrift für Gottfriend Marron zum 75. Geburtstag, Hannover, 2003, 6696; and Herbert Zschelletzschky, 'Vorgefecht des reformatorisches Bildkampfes. Zu Cranachs Holzschnitt “Himmelwagen und Höllenwagen des 
Andreas Bodenstein von Karlstadt” von 1519’, in Peter Heinz Feist, Ernst

Ullmann and Gerhard Brendler, eds, Lucas Cranach. Künstler und

Gesellschaft. Referate des Colloquiums mit internationaler Beteiligung zum

500. Geburtstag Lucas Cranach d. Ä., Wittenberg, 1973, 102-106.

Mühlhaupt and Thümmel focus upon textual issues, and Zschelletzschky

addresses context in more detail than iconography. See also William Wallace McNiel, 'Andreas von Karlstadt and Thomas Müntzer: Relatives in Theology and Reformation', PhD dissertation, Queen’s University Ontario, 1999, 9699; Konrad Hoffman, '”Fuhrwagen” des Andreas Bodenstein von Karlstadt', in Martin Luther und die Reformation in Deutschland. Ausstellung zum 500 Geburtstag Martin Luthers, Frankfurt am Main, 1983, 244; Werner Hofmann, ed., Luther und die Folgen für die Kunst, Munich, 1983, 117 and 191-192; Konrad von Rabenau, 'Der Fuhrwagen. 1519’, in Kunst der Reformationszeit, Berlin, 1983, 356-357; and Ulrich Bubenheimer, 'Andreas Rudolff Bodenstein von Karlstadt. Sein Leben, seine Herkunft, und seine innere Entwicklung', in Wolfgang Merklein, ed., Andreas Bodenstein von Karlstadt 1480-1541. Festschrift der Stadt Karlstadt zum Jubiläumsjahr 1980, Karlstadt, 1980, 19-28.

${ }^{2}$ Hermann Barge (who was not able to see a copy of the Wagen, then believed lost) dated it to the last days of March because on March 20, 1519, Karlstadt sent Spalatin a number of copies which he was to send to important people. Hermann Barge, Andreas Bodenstein von Karlstadt, Leipzig 1905 (repr. Leipzig 2007), 2 vols, vol. 1, 464-5. However, in the same letter Karlstadt also wrote that it would not be possible to print the cartoon owing to the length of the mottoes. Barge therefore assumed that Karlstadt must have added the texts in by hand. But the passage in the letter is referring to the impossibility of a vernacular edition, that is, a version in German, which would suggest that the Latin edition existed by then: Johann Friedrich Olearius, Scrinium Antiquarium, Idiocheira Antiquitatis Fragmenta: Summorum Videlicet In Eccles. Acad. Et Schol. Superiore Aevo Virorum, 
\#

Manuque Ipsorum Scriptas Nec Hactenus Unquam Editas Plus Centum

Epistolas Et Schedas Pandens Atque Communicans, Halle, 1671 [VD 17

39:141518W], 45, 20 March 1519. As Barge pointed out, Adelmann von

Adelmannsfelden had a copy by 22 April; and Luther mentioned the

Leipzigers' anger at the cartoon in a letter to Johann Lang of 13 April. From

an earlier letter Karlstadt wrote to Spalatin we know it was being prepared for the press in January: 'Caeterum currum , qui officinam ob impedimenta

celeberrimi nostri pictoris nondum est ingressus, quam cito excusus redierit, mittam’, Olearius, Scrinium Antiquarium, 56, 14 January 1519, a witty comment suggesting that Karlstadt's main contribution was done and that Cranach's other duties were holding up its appearance.

Moreover, Karlstadt's explanation of the Wagen, the Auszlegung (discussed below) included a dedication written on 3 April, with the final page of the booklet dated 18 April 1519. As Karlstadt expressly says in the preface of 3 April, the Auszlegung was written because some of his supporters told him they couldn't understand the top half of the image. Andreas Karlstadt, Auszlegung vnnd Lewterung etzlicher heyligenn geschrifften...in den figurn vnd schrifften der wagen..., Leipzig, 1519 [VD 16 B 6113], sig. A ii verso. So for them to have had time to read the printed broadsheet and let Karlstadt know their misgivings, and Karlstadt to have a chance to respond and begin writing the treatise, it would seem likely that the Latin Wagen was in print shortly before 20 March 1519, and the German, at some point after 20 March.

3 ‘daß gut wandern war und viel Leut darzu kommen konnten’, Friedrich Myconius, Geschichte der Reformation, ed. Otto Clemen, Leipzig, 1914 (repr. Gotha, 1990), 31; and see, on the debate, Markus Hein and Armin Kohnle, eds, Die Leipziger Disputation 1519, Leipzig, 2011.

${ }^{4}$ Two copies of the German Wagen survive: one in the German Historical Museum (inventory no. Gr 53/1), and another in Hamburger Kunsthalle (inventory no. 12794; the copy reproduced for this article). Only a fragment 
\#

of the Latin cartoon still exists, held at the Evangelisches Predigerseminar

Bibliothek, Wittenberg.

${ }^{5}$ Indeed, Karlstadt at first thought that a vernacular version of the cartoon

simply would not have room for the text: Olearius, Scrinium antiquarium, 45.

${ }^{6}$ Robert W. Scribner, For the Sake of Simple Folk: Popular Propaganda for the German Reformation, second edition, Oxford, 1994.

${ }^{7}$ Translations from the Wagen are included in the main text of the article to help the reader visually navigate the broadsheet.

${ }^{8}$ Martin Luther, Ein Sermon gepredigt tzu LeipSak / vffm Schloß am tag Petri vn[d] pau / li im xviiij. Jar, durch den wirdigen vater Doctorem / Martinu[m] Luther augustiner zu Wittenburgk, Leipzig, 1519 [VD 16 L 6194]. This was the first image of the reformer and it shows him with his monogram the rose. ${ }^{9}$ Horst Appuhn, ed., Johann Siebmachers Wappenbuch, second edition, Dortmund, 1988, 2 vols, vol. 2, plate 182, second row, fifth shield: ‘V[on] Bodenstein.' This is not generally recognised, and the only other identification is in Bubenheimer, 'Andreas Rudolff Bodenstein von Karlstadt', 6 and 9.

${ }^{10}$ Lyndal Roper, Martin Luther: Renegade and Prophet, London, 2016, 21758.

${ }^{11}$ See D. Martin Luthers Werke: Kritische Gesamtausgabe, Weimar, 1883-, Briefe (hereafter WB), vol. 1, 32, 2 January 1517 in which Scheurl seeks Luther’s friendship; and 33, 27 January 1517 for Luther’s reply.

${ }^{12}$ WB vol. 1, No. 36, 1 April 1517 (Scheurl to Luther), 91-2, and Luther’s outraged 'Et hoc est testimonium fidelis amicitiae tuae, quam ultro mihi obtulisti’ WB vol. 1, No. 77, 19 May 1518, 178:5-6.

${ }^{13}$ WB vol. 1, No. 77, 19 May 1518, 177-9; No. 82, 15 June 1518, 182-4; Andrew Pettegree, Brand Luther: 1517, Printing, and the Making of the Reformation, London and New York, 2015, 96-7.

${ }^{14}$ Barge, Andreas Bodenstein von Karlstadt, vol. 1, 117. 
$\#$

${ }^{15} \mathrm{He}$ had first published three sets of counter-theses to Karlstadt's, also substantially shorter than Karlstadt's collection; the twelve theses were printed alongside a letter to Mathaeus Lang of Salzburg. Erwin Iserloh, Johannes Eck (1486-1543). Scholastiker, Humanist, Kontroverstheologe, Münster, 1981, 29.

${ }^{16}$ When Luther received a copy of Eck's twelve theses in February (he was sent them by Willibald Pirckheimer in Nuremberg, and received a copy from Eck himself a fortnight later), he republished them alongside twelve counter theses of his own and an open letter to Karlstadt in which he complained of Eck’s behaviour: Martin Luther, Disputatio D. Johannis Eccij et P. Martini Luther in Studio Lipsensi. Future, Wittenberg, 1519 [VD 16 E 318]; WB, vol. 1, No. 132 and Beilage [4 or 5? February 1519], 315-23. This made the debate inevitable.

${ }^{17}$ Johann Georg Walch, Dr Martin Luthers Sämmtliche Schriften, St Louis, 1880-1910 (revised version of the Halle Edition, 1740-1753), 23 vols, vol. XV, 1204-5 (Sebastian Fröschel); his account was not written until 1566; that of the Saxon chancellor Pfeiffer is also a later account: ibid, 1208. Rubius mentions the incident in his contemporary poem: Johannes Rubius, Eyn neu buchlein von d'loblichen disputation offentlich gehalten vor fursten vnd vor hern vor hochgelarten vnd vngelarten yn der warden hochgepreusten stat Leyptzick inn reymen weisz, Leipzig 1519 [VD 16 R 3409].

${ }^{18}$ Martin Brecht, Martin Luther, trans. James L. Schaaf, Minneapolis, 198593 (Stuttgart, 1981-1987), 3 vols, vol. 1, 337-8.

${ }^{19}$ Brecht, Martin Luther, vol 1, 322-43; Christian Winter, 'Die Protokolle der Leipziger Disputation', in Hein and Kohnle, eds, Die Leipziger Disputation 1519.

20 'Dieweil ich aber durch frewntliche gonder vorstendiget/ das wenig solche meinung aus den schriefften des obersten wagen fassen konnen/ vnd haben derhalben ein erleuterung begert....' Karlstadt, Auszlegung, sig. A ii verso. Also see note 2, above. 
\#

${ }^{21}$ See below for further discussion of this figure.

${ }^{22}$ Johannes Eck, Doctor Martin ludders Underricht an Kurfursten von

Sachssen, disputation zu Leypszig belangent: vnnd D. Eckius briue, von der selbigen Autor, Augsburg, 1520 [VD 16 L 6831 = E 279; L 6832 = E 280].

By a strange irony, this pamphlet became the source for many of the letters, which are given in German and not their original Latin in the Weimarer Ausgabe of Luther's letters.

${ }^{23}$ Thomas W. Best, ed., Eccius dedolatus: A Reformation Satire, Lexington, KY, 1971. The title might be translated as 'Eck's corners planed', a pun on Eck’s name which means ‘corner’ in German.

${ }^{24}$ Best (ed.), Eccius dedolatus, Introduction, 22-5; Karlstadt responded to the threat of martyrdom with a treatise on Gelassenheit: Edward J. Furcha, ed. and trans., The Essential Carlstadt: Fifteen tracts, Waterloo, Ontario, 1995, 28-30; Andreas Karlstadt, Missiue von der aller hochsten tugent gelassenhait, [Augsburg], [1520] [VD 16 B 6170]. On Karlstadt’s theology, see Barge, Andreas Bodenstein von Karlstadt; Amy Nelson Burnett, Karlstadt and the Origins of the Eurcharistic Controversy: A study in the circulation of ideas, New York, 2011; and Bubenheimer, 'Andreas Rudolff Bodenstein von Karlstadt’.

${ }^{25}$ For examples see Frances Carey, ed., The Apocalypse and the Shape of Things to Come, London, 1999.

${ }^{26}$ Hans von Leonrod, Hymelwag auff dem, wer wol lebt vn[d] wol sterbt fert in das reich der himel. Hellwag auff dem, wer übel lebt vn[d] übel stirbt fert in die ewigen verdamnuß, Augsburg, 1517 [VD 16 L 1238].

${ }^{27}$ Sachiko Kusukawa, The Transformation of Natural Philosophy: The Case of Philip Melanchthon, Cambridge, 2006, 45 and 65.

${ }^{28}$ On this point in general terms see Mühlhaupt, ‘Karlstadts “Fuhrwagen”', 62.

${ }^{29}$ Jean Michel-Massing, 'The Triumph of Caesar by Benedetto Bordon and Jacobus Argentoratensis’, Print Quarterly 7:1, 1990, 2-21. See also Larry 
\#

Silver, 'Triumphs and Travesties: Printed Processions of the Sixteenth

Century', in Larry Silver and Elizabeth Wyckoff, eds, Grand Scale:

Monumental Prints in the Age of Dürer and Titian, New Haven, 2008, 15-32.

${ }^{30}$ Suzanne Boorsch, 'The Oversize Print in Italy’ in Silver and Wyckoff, eds, Grand Scale, 35-51.

${ }^{31}$ Barge, Andreas Bodenstein von Karlstadt, vol. 1, 49-55; Bubenheimer, 'Andreas Rudolff Bodenstein von Karlstadt', 14-15.

${ }^{32}$ Barge, Andreas Bodenstein von Karlstadt, vol. 1, 69.

${ }^{33}$ Werner Weisbach, Trionfi, Berlin, 1919, 16 and 34.

${ }^{34}$ John Shearman, 'The Florentine Entrata of Leo X, 1515', Journal of the Warburg and Courtauld Institutes 38, 1975, 136-54. Such events clearly mattered to audiences beyond Italian regions. At least one report of a procession by Leo X in 1519 would be published in German: Anon., Verkundu[n]g Bäbstlicher Procession, [Landshut], [1519] [VD 16 F 2615]. ${ }^{35}$ Jakob Locher, Continentur. Jn hoc opusculo a Jacobo Locher Philomuso facili Syntaxi concinnato: Vitiosa sterilis Mule ad musam: roscida lepiditate predictam, Comparatio : Currus sacre theologie triumphalis. ... Elogia Quattuor Doctorum Ecclesie , cum Epigra[m]matibus ..., Nuremberg, 1506 [VD16 L 2230], sigs C iii verso - C iv recto. See Meister um Albrecht Dürer, Nuremberg, 1961), 211 and 215, cat. no. 385. Briefly discussed in Zschelletzschky, 'Vorgefecht des reformatorisches Bildkampfes’, 106.

${ }^{36}$ Larry Silver, Marketing Maximilian: the Visual Ideology of a Holy Roman Emperor, Princeton, 2008.

${ }^{37}$ McNiel, ‘Andreas von Karlstadt and Thomas Müntzer', 12 and 24-26, and Barge, Andreas Bodenstein von Karlstadt, vol. 1, 47-48 and 56.

${ }^{38}$ Ulrich von Hutten, Ioannis Capnionis viri praestantissimi Encomion ... [Hagenau], [1518] [VD 16 H 6414]. See Wilhelm Kühlmann, 'Ulrich von Huttens Triumphus Capnionis - Der Triumph Reuchlins. Bildzeichen, Gruppenbilding und Textfunktionen im Reuchlin-Streit', in Reuchlins Freunde und Gegner. Kommunikative Konstellationen eines 
\#

frühneuzeitlichen Medienereignisses, ed. Wilhelm Kühlmann (Ostfildern, 2010), see 91-93 on publication dates.

${ }^{39}$ Zschelletzschky, 'Vorgefecht des reformatorisches Bildkampfes', 104.

40 ، 'ut senciant se morsos, si explicuerint interiora', Olearius, Scrinium antiquarium, 37, 20 October 1518, Cited in Bubenheimer, 'Andreas Rudolff Bodenstein von Karlstadt', 19. From the Latin cartoon itself, it is clear that Karlstadt certainly believed that he was responding to enemies: at the very centre of the image, as part of his own name and his claim to authorship, he states darkly that he was 'driven' to publish by 'plots' (insidiis coactus). In a letter in February, he averred that the image was directed not against the Pope, but only the scholastics; and he was careful at this time not to attack the power of the pope directly: Barge, Andreas Bodenstein von Karlstadt, vol. 1, 143; Olearius, Scrinium Antiquarium, 43-4, 24 February 1519, and see discussion below.

${ }^{41}$ WB vol. 1, No.192, 18 August 1519, Karlstadt and Luther to Frederick the Wise, 465-78, 466: 'Ich hab niemand genennt noch ausgemalt in den Bildern des Wagens, sondern die gemeine Jrrtumb der Theologen angezeigt'; but this was in the context of excusing himself to his ruler. See also Hofmann, ed., Luther und die Folgen für die Kunst, 192.

42 'ein gerechten sunder// eyn bußwircker/ vnnd creutztrager’, Karlstadt, Auszlegung, sig. C iv verso - D i recto.

${ }^{43}$ Indeed, he cannot be directly connected with any specific textual or visual source. Aspects of the figure may have been prompted by the 'shaking hands' ('zitterdern henden') of the elderly pilgrim who is the main voice of Leonrod, Hymelwag, see eg. sig. A ii recto, sig. B iiij verso, or the Petrarchan figure of Time (see eg. fig. 5). But these possible reference points concern only the age of figure, and not his more fundamental status - for Karlstadt - as a sinner.

${ }^{44}$ The passage is not a quotation from Augustine but a summary paraphrase of the key points, which does however stick quite closely to the terms Augustine uses. 
\#

45 'Es wurt auch keyn Prediger Monich/ welcher sich eyn teyl/ gern tzu frembden sachen benotten/ vnd selbst tzuschaffen machen/ beweysen/ das obbedacht bildt eine prediger Cappen hab’, Karlstadt, Auszlegung, sig. D i recto.

46 'in den Druck ein Wagen zu geben, wie E. Ch. G. Doctor Carlstat tan hat und mich ganz spöttlich mit ausgedruckten Namen darin verschmächt. Ich künt auch wohl ein Wagen machen, aber ich wollt ihn nit darinnen setzen’ WB vol. 1, No. 192, 461:77-80. On Eck’s reaction, see Zschelletzschky, 'Vorgefecht des reformatorisches Bildkampfes', 105.

47 'Zum andern läßt er sich meinen Wagen verdrießen und meinet auch wohl einen zu machen, aber nit Roß, sondern vielleicht Esel darein setzen. ...Jch laß ihn Wagen machen und Esel darein setzen, wie er will, vielleicht findt man einen Treiber darzu', WB vol. 1, No. 192, 466:46; 51-2.

${ }^{48}$ Jch hab nit geklagt über das Gemäl, dann ich acht, er sitz selb auf dem untern Wagen; aber daß er mich mit ausgedruckten Worten antast und schmächt: wann ich Esel in Wagen satzte, wollt er die Esel treiben; laß ich sein. Kann ers, so siegt er wohl in das Welschland', WB vol. 1, No. 192, 8 November 1519, 480:39-43. Despite this bitter exchange between Karlstadt and Eck, the figure in the lower cart has previously been identified by scholars simply as a monk, a Franciscan, a scholastic theologian or a ‘conceited cleric’. Von Rabenau, 'Der Fuhrwagen. 1519’, 357; Bubenheimer, ‘Andreas Rudolff Bodenstein von Karlstadt', 19; Mühlhaupt, 'Karlstadts “Fuhrwagen”', 62; Zschelletzschky, 'Vorgefecht des reformatorisches Bildkampfes’, 104.

${ }^{49}$ von Leonrod, Hymelwag, sig. D i recto.

${ }^{50}$ Martin Luther und die Reformation in Deutschland, 226-27.

${ }^{51}$ Max J. Friedländer and Jakob Rosenberg, Die Gemälde von Lucas Cranach, second edition, Basel, 1979, 90.

52 Timothy Husband, The Wild Man: Medieval myth and symbolism, New York, 1980. 
$\#$

${ }^{53}$ Husband, The Wild Man, 89.

${ }^{54}$ Lynn Frier Kauffmann, The Noble Savage: Satyrs and Satyr Families in Renaissance Art, Ann Arbor, 1984.

${ }^{55}$ Husband, The Wild Man, 102 and 107.

56 'der heilig Augustinus gesagt/ wir habe[n] den feind in vns.’ Karlstadt, Auszlegung, sig. C ij verso.

${ }^{57}$ Karlstadt, Auszlegung, sig. Eiij recto. See Zschelletzschky, 'Vorgefecht des reformatorisches Bildkampfes’, 104.

${ }^{58}$ Mühlhaupt, ‘Karlstadts “Fuhrwagen”’, 62.

${ }^{59}$ Karlstadt, Auszlegung, sig. A iiij recto.

${ }^{60}$ See, for example, Andreas Karlstadt, Von vormugen des Ablas: wider Bruder Franciscus Seyler parfuser ordens, Wittenberg, 1520 [VD 16 B 6255].

${ }^{61}$ F. W. H. Hollstein, ed., German engravings, etchings and woodcuts ca. 1400-1700, Blaricum, 1986, vol. XV, 93.I.

${ }^{62}$ Martin Luther und die Reformation in Deutschland, 230-231.

${ }^{63}$ Ronald J. Sider, Andreas Bodenstein von Karlstadt: The development of his thought, 1517-1525, Leiden, 1974, 87. Mühlhaupt, ‘Karlstadts

"Fuhrwagen”, 75, declares that the broadsheet is in no way anti-papal.

${ }^{64}$ Andreas Karlstadt, Von Bepstlicher heylickeit, Wittenberg, 1520 [VD 16 B 6253], sigs Biij verso - C ij verso. Raphael’s 1514 fresco of Pope Leo I meeting Attila is often thought to be a disguised portrait of Leo X riding his favourite horse. Elisabeth Garms-Cornides, 'Der reitende Papst. Ein Beitrag zur Ikonographie des Papsttums by Jörg Traeger’ (review), Print Quarterly 55.3, 1973, 454.

${ }^{65}$ Karlstadt, Von Bepstlicher heylickeit, sig. Biij verso. See discussion of this passage in McNiel, 'Andreas von Karlstadt and Thomas Müntzer', 223. The drayman figure in the Wagen sits alongside and draws attention to a second saddle and ornate blanket on the paired horse. 
$\#$

${ }^{66}$ 'qvod nihil constituerim vehiculo meo ineptire contra Romanum

Pontificem', Olearius, Scrinium Antiquarium, 43, 24 February 1519, and see

Bubenheimer, ‘Andreas Rudolff Bodenstein von Karlstadt', 28.

${ }^{67}$ Bubenheimer, ‘Andreas Rudolff Bodenstein von Karlstadt’, 29.

68 'eine Art mißglückter St. Georg.’ Mühlhaupt, ‘Karlstadts “Fuhrwagen”’,

62. Zschelletzschky suggests, without further evidence, that this may be a scholastic such as Duns Scotus or Aristotle.

${ }^{69}$ See Cranach’s own typical St George, 1520-25, in Friedländer and

Rosenberg, Die Gemälde von Lucas Cranach, 98.

${ }^{70}$ The Latin version has the same rough re-cutting, so this cannot be attributed to the problems of fitting in a different text.

${ }^{71}$ It is also possible that Karlstadt wishes to parody the 'barefoot' Franciscans, although if that was his intention the attempt is unsuccessful.

${ }^{72}$ Karlstadt's Auszlegung offers no guidance for reading this figure.

${ }^{73}$ Augustine, De spiritu et littera, Wittenberg, 1519 [VD 16 A 4237]. The debt Luther owed Karlstadt was clear when he dedicated his 'In epistolam Pauli ad Galatas' of early 1519 to Petrus Lupinus and Karlstadt, D. Martin Luthers Werke: Kritische Gesamtausgabe, Weimer, 1883-, Schriften, vol. 2, 437. On Staupitz, see Roper, Martin Luther, 67-76 and 101-3.

${ }^{74}$ Barge, Andreas Bodenstein von Karlstadt, vol 1, 146-7.

${ }^{75}$ Karlstadt, Auszlegung, sig. E v verso.

${ }^{76}$ Karlstadt, Auszlegung, sig. C iii verso.

77 'Gelas eigen willen alles dein vnd dich.' Karlstadt, Auszlegung, sig. C iv verso.

${ }^{78}$ Karlstadt glosses this in the Auszlegung, sig. E iii verso.

${ }^{79}$ WB vol. 2, No. 400, 28 April 1521, 305-6.

${ }^{80}$ See Natalie Krentz, Ritualwandel und Deutungshoheit. Die frühe Reformation in der Residenzstadt Wittenberg (1500-1533), Tübingen, 2014; Jens-Martin Kruse, Universitätstheologie und Kirchenreform. Die Anfänge der Reformation in Wittenberg 1516-1522, Mainz, 2002; Nikolaus Müller, 
Die Wittenberger Bewegung 1521 und 1522. Die Vorgänge in und um Wittenberg während Luthers Wartburgaufenthalt. Briefe, Akten u. dgl. und Personalien, Leipzig, 1911; and Stefan Oehmig, 'Die Wittenberger Bewegung 1521/22 und ihre Folgen im Lichte alter und neuer Fragestellungen. Ein Beitrag zum Thema (Territorial-)Stadt und Reformation,' in Stefan Oehmig, ed., 700 Jahre Wittenberg. Stadt, Universität, Reformation, Weimar, 1995.

${ }^{81}$ The viewer will then conclude that the upper section is good, the lower, harmful.

82 'vnßere augen bulen/vnd puben/vnd ist ye war/ das sie allesampe huren vnd eheprecheryn sein/die bilder eheren/ oder vmb hylff ansuchen' .... 'mein hertz ist von Jugend auff yn eher erbiethung vnd wolachtung der bildnis ertzogen vnd auffgewachßen. vnd ist mir ein schedliche forcht eingetragen / der ich mich gern wolt endletigen / vnd kan nit. Alßo stehn ich in forcht / das ich keynen olgotzen dorfft verbrennen.’ Furcha, The Essential Carlstadt, 115, 117; Karlstadt, Von abtuhung der Bylder / Vnd das keyn Betdler vnter den Christen seyn sollen, Wittenberg, 1522 [VD16 B 6215], sigs C iii verso and $\mathrm{C}$ iv verso.

${ }^{83}$ On works that it influenced see also Zschelletzschky, 'Vorgefecht des reformatorisches Bildkampfes’, 106.

${ }^{84}$ Joseph Leo Koerner, The Reformation of the Image, Chicago, 2004, 119122, 192-193, 201-202.

${ }^{85}$ In Hans Heinrich Freyermut, Triumphus veritatis, Speyer, 1524 [VD16 ZV 6175]. See Martin Luther und die Reformation in Deutschland, 220; and on the treatment of Karlstadt in this work (at the favoured right hand of Christ) see Calvin August Pater, Karlstadt as the Father of the Baptist Movements: The emergence of lay Protestantism, Toronto, 1984, 295-300. 